\author{
ĐORĐE ĐURIĆ \\ University of Novi Sad \\ Faculty of Philosophy, Department of History \\ djdjuric@gmail.com
}

\title{
RUSSIAN HISTORIOGRAPHY OF THE PETROVSKY ERA
}

\begin{abstract}
This paper deals with the development of Russian historiography during the reign of Peter the Great. During the reign of this reformer ruler historiography was modernized in line with other general reforms. There was a significant increase in the number of documents that were created as a result of the establishment of new departments and sections in the state administration. These documents would become historical sources for writing contemporary history, which, among other things, had the task of glorifying the actions of rulers. Historiography was also modernized in terms of methodology because Western models of that time became generally accepted.
\end{abstract}

Keywords: Russian historiography, an era of Peter the Great, historical consciousness, Theophanes Prokopovich, Alexei Mankiev, history of Russia, Fyodor Polikarpov, Peter Shafirov, Boris Kurakin.

$\mathrm{T}$

The rapid development of historiography in Russia occurred in the era of Peter the Great and the first decades after his reign. The sweeping reforms that were implemented at that time changed Russia fundamentally. State institutions were organized after an absolutist model. The reforms were implemented in the army, the navy, the political and economic systems, education and the church. There were almost no parts of public affairs in Russia that were left intact. The establishment of institutions modeled on Western European absolute monarchies inevitably led to an increase in bureaucracy, which was organized into various "sections", "administrations", "departments" etc., and thus started producing piles of archival (historical) material. ${ }^{1}$ This was particularly evident in the diplomatic service, which had to keep records and leave detailed reports on their activities according to the new rules. For example, before Peter I's departure on his 'Great mission' to the West at the end of 1696, the diplomatic administration was instructed to prepare a study on the external relations of Russia with the countries to which they planned to go and on the titling practices of their rulers and aristocracy since $1580 .^{2}$ Since the time of the reign of Peter the Great a rule was introduced concerning the keeping of official

\footnotetext{
${ }^{1}$ Molchanov 2003: 12-34; Kostomarov 1992: 213-232.

${ }^{2}$ Rogozhin 2004: 86-87; Karpov 1997: 26-29.
} 
'journals' and records of military maneuvers and military and naval campaigns, which were written by commanders of units. Another significant source are the official court reports journals, a kind of chronicles which recorded daily activities of emperors and court services. All these notes would become very useful sources for the history of that time because they recorded in detail all the important facts following the model of western bureaucracy. ${ }^{3}$

After the abolition of the Patriarchate in 1721 and a direct subjugation of the church to state authorities, Peter issued several decrees regarding the collection of historical sources which had previously been kept in monasteries or in "dilapidated church towers". ${ }^{4}$ Thus, keeping chronicles and writing history was slowly transferred from the church to the state. Peter was personally involved in giving recommendations on how history should be written. ${ }^{5}$ Apparently relying on western models from previous centuries, he recommended to Russian authors to stop writing history since the ancient times using the Biblical form and instead to write secular history, the focus of which would be the Russian state. Of course, special attention had to be paid to him personally and they were supposed to describe his campaigns, reforms and other events. ${ }^{6}$

These expectations were partially fulfilled by Alexei Ilyich Mankiev, who wrote the book The Core of Russian History. ${ }^{7}$ The author claims that he was personally "ordered" by the emperor to write a work which would primarily describe "His Imperial glorious deeds and splendid victories over the enemies".

Alexei Ilyich Mankiev (Mankievich) was of Polish origin. He served in the Russian diplomacy as a secretary of the embassy in Sweden. Because of the Northern War he spent as much as 18 years in captivity in Sweden, where he wrote his book some time around 1715. After the liberation, again in Russian service, he participated in the establishment of the borders after the Treaty of Nystad. He died in 1723. Although narrative sources claim that he personally showed his work to Peter, it was not published until 1770, when it was edited by G. F. Miller, a Russian academician of German origin. The Core of Russian History was written on the basis of Russian chronicles, as well as foreign books available to the author in Sweden. Mankiev tried to analyze and interpret the events that he was describing. Although he began his book with Biblical genealogies, he actually wrote a secular history and made a serious critique of the sources, both Russian and foreign ones.

\footnotetext{
${ }^{3}$ Rogozhin 2004: 87-88.

${ }^{4}$ Gerasimenko 2002: 27-28.

${ }^{5}$ The propensity of Peter the Great for history is obviously linked to the beginning of his education. His biographers claim that N. M. Zotov, his teacher, told his student about the works of St. Vladimir, Alexander Nevsky, Dmitriy Donskoy. Peter often read imperial genealogies, the Nikon Chronicle and other old chronicles. He obviously read the works of classical literature, becuase later in his writing he mentioned the fall of Carthage and of Constantinople.

${ }^{6}$ Gerasimenko 2002: 27-28.

7 А. И. Манкиев Ядро Российской истории, сочиненное ближним стольником и бывшим в Швеции резидентом, князь Андреем Яковлевичем Хилковым, в пользу российскаго юномества, и для всех о российской истории краткое понятие иметь желающих в печать изданное, с предисловием о сочинителе сей книги, и о фамилии князей Хилковых, [предисл. Г. Ф. Миллера], Москва, Печатано при Императорском Московском Университете, Иждивением книгопродавца и Университетскаго Переплетчика Христиана Ридигера, 1770, Объем: [16], 392, [8] с.; $8^{\circ}$; The book was reprinted in 1784, 1791. and 1799.
} 
The book which he finished approximately in 1715 covered the period until 1712, which partially fulfilled the emperor's desire to describe "his famous actions". 8 In a "rationalist" manner Mankiev deduced a genealogy of the Russian (and Polish) people from Meshech, the sixth son of Japheth, and added that the Russian people "do not fly in the sky and do not take gods, heroes, refugees or outlaws as ancestors, like the Greeks and Romans did". ${ }^{9} \mathrm{He}$ was among the first to conduct a periodization of Russian history. According to him, there are 5 eras: 1) from Rurik (whose origin derives from the Roman emperors) to Andrei Bogolyubsky and Vsevolod the Big Nest; 2) from the Mongol invasion to Ivan III; 3) from the death of Ivan III to the death of Fyodor Ivanovich; 4) from Boris Godunov to Mikhail Romanov, and 5) from Mikhail Romanov to the imperial rule of Peter the Great (ending with 1712). The book deals mainly with political history and glorifies autocracy. It is interesting that simultaneously with Russian history Mankiev paid close attention to the most important events in Europe (the discovery of America, the English revolution, etc.) thus placing Russian history in a more general context. ${ }^{10}$

Other historians of the Petrovsky era include: Fyodor Polikarpov, Peter Pavlovich Shafirov and Boris Ivanovich Kurakin.

Polikarpov, a director of the Moscow typography, was educated in the spirit of the Russian culture of the 17th century and he did not favor the reforms carried out by Peter the Great. He studied at the Slavo-Greek-Latin Academy, which was prestigious at the time, and later became a teacher there. He translated books from classical languages and was considered a connoisseur of Russian antiquities. Under his administration and supervision the Moscow typography printed the famous "Slavic" primers and grammars, some of which (the speller of Theophanes Prokopovich and the grammar of Meletius Smotrytsky) were among the major textbooks that Serbs used in the first half of the 18th century. ${ }^{11}$ In 1708 Peter the Great commissioned Polikarpov to write the history of Russia on the basis of yearbooks and other documents of Russian origin, but without covering the creation of the world and the history of other countries. Polikarpov was explicitly instructed to start his presentation from the 16th century (the beginning of the centralization and union of the Russian states into one powerful country) and to finish it at the reign of Peter the Great with the intention to justify the introduction of absolutism. Polikarpov wrote a shorter and a longer version of the commissioned book, but neither of the versions were "favorable" enough for the emperor so the book remained unpublished.

Peter Pavlovich Shafirov (1669-1739) was well educated. He spoke French, German, Latin, Polish and Dutch. This enabled him to occupy a high position in the diplomatic service. He not only translated diplomatic documents for Peter the Great, but also books from various fields of science and literature, which were assessed as useful to the emperor. As such, he was a member of the Great Embassy in the period 1697-98. On that occasion the emperor himself became convinced of his abilities and played a major role in the choice of Shafirov as Peter's Vice-Chancellor in 1709. He participated in the negotiations

\footnotetext{
${ }^{8}$ Obolensky 1858: 19.

${ }^{9}$ Mankiev 1770: 5

${ }^{10}$ Rogozhin 2004: 93-94.

${ }^{11}$ Mladenović 2004: 519.
} 
concerning the alliance of Russia, Poland and Denmark against Sweden in 1699 and in all major diplomatic actions during the North War and the war against Turkey. At the end of Peter's reign he fell out of favor, but then he was reinstated again. He played an important role at the court even with Peter's heirs. As a very knowledgeable man dedicated to the most important state affairs, he was suitable for writing history, which was probably suggested by F. S. Saltykov, the Russian ambassador in London. Shafirov's work with a renaissance title: Reflections on the laws and reasons of his Imperial Majesty Peter I ... to start a war against the Swedish king Karl XII in 1700, and which of the warring parties showed more affection toward reconciliation, and who was responsible for an extension of the war where a lot of blood of Christians was spilled and a lot of countries were destroyed... All described impartially, on the basis of ancient and new acts, contracts and records of military operations, with moderation and truth... ${ }^{12}$, was written with obvious political ambitions to justify the long and bloody war before the Russian and European public, but also to justify Russia's pretensions to the Baltic coast on the basis of a series of documents published in the book. This was supported by the fact that already in 1717 the book was translated into German and was distributed all over Europe. ${ }^{13}$ Later it was reprinted on the eve of the signing of the Treaty of Nystad. ${ }^{14}$ The book can be considered a defense of Peter the Great and especially his foreign policy. However, it also had a very large original significance because it used and partially published documents connected with the relations between Russia and Sweden since mid 16th century until the Northern War.

Prince Boris Ivanovich Kurakin (1676-1727) belonged to the highest Russian nobility. He was a brother-in-law of Peter the Great since he married the sister of the emperor's first wife Evdokia Lopuhina. He participated in the Azov campaigns in the period 1695-1696, while in the battle of Poltava in 1709 he commanded the elite Semyonovsky regiment. During his diplomatic service, he traveled in several missions and was a permanent Russian ambassador in Rome, England, Hanover, Holland and France. Besides the great diplomatic and military experience he also possessed a rich collection of letters and documents, which was the basis for several books which can be considered historical. He wrote The Diary and Travel Observations, which covered the period from 1705 to 1708 when he stayed in various

\footnotetext{
12 Рассуждение, какие законные причины его царское величество Петр первый царь и повелитель всероссийский и протчая, и протчая, и протчая: к начатию войны против Короля Карола 12 , Шведского 1700 году имел, и кто из сих обоих потентатов в время сеи пребывающей войны более умеренности и склонности к примирению показывал, и кто в продолжение оной с толь великим разлитием крови християнской, и разорением многих земель виновен; и с которой воюющей страны та воина по правилам христианских и политичных народов более ведена. Все беспристрастия фундаментально из древних и новых актов и трактатов, також и из записок о воинских операциях описано, с надлежащей умеренностию и истинной. Так что в потребном случае может все, а именно: Первое оригинальными древними, меж коронами Российской и Шведской постановленными трактатами, грамотами и канцелярскими протоколами, також многое и без пристрастными Гисториями со стороны российской доказано, и любопытным представлено быть; с соизволения Его Царского Величества всероссийского собрано и на свет издано в царствующем Санкпитербурхе, Лета Господня 1716, а напечатано 1717, $\mathrm{f}^{\circ}, 10$. The second edition was published in 1721 .

${ }^{13}$ Raisonnement was fur rechtmassige Ursache Se. Cz. Majest. Petrus der Erste Czaar der Reussen etc. etc. etc. gehabt den Krieg wieder den Konig in Schweden Carolum den XII-ten A Christi 1700 anzufangen.

${ }^{14}$ Pekarsky 1862: 212-219.
} 
diplomatic missions in Eastern Europe. In an autobiography entitled The Life of Prince Boris Kurakin he described his life from 1676 to 1710 and all the important events in the empire, including Peter's reforms, at the same time publishing the lists of state expenditures and revenues. In The Records of the Russo-Swedish War, which included the year 1710, he used the memories of his contemporaries and the press of the time. He explained in detail the military and diplomatic events related to this war. ${ }^{15}$ His most important historical work is The History of Emperor Peter Alekseevich. The emperor's biography is divided into three parts in which Kurakin elaborated internal politics and reforms, the war with Sweden and the diplomacy of the Petrovsky time. The special value of work lies in numerous descriptions of Peter's contemporaries as well as in impartial descriptions of the emperor's adversaries. This book was supposed to be only a segment of the unfinished History of the Slavic Russian Empire for which Kurakin wrote a detailed outline. He had planned to use reliable sources and cover the period from the earliest Kievan princes to his own time. ${ }^{16}$

Theophanes Prokopovich (1681-1736) is one of the most important figures in the intellectual and spiritual life of the Petrovsky era. He left a deep trace in historiography.

He was born to a merchant family in Kiev, as Eleazar (Elisha) Prokopovich. He graduated from the Kiev Mohyla Academy and then in 1698 he went to Rome to continue his education. To be admitted to the seminary of St. Athanasius in Rome, which was managed by the Jesuits, he transferred to the Uniat Church and became a monk in the local monastery of St. Basil the Great. During his education, he drew attention to himself with his diligence and erudition, so Pope Clement XI himself proposed that he remain in Rome. He declined the offer and upon the completion of his training he returned to Kiev, where he was re-baptized in an Orthodox rite and in 1704 became a monk called Theophanes. During his education in Rome he was introduced to the western science and became a follower of the views of Descartes and Bacon. He gained a dislike of Catholic proselytism, whereas Protestant rationality and pragmatism were considerably closer to his heart. ${ }^{17}$

After returning to his homeland, he taught theology, rhetoric, philosophy and poetry at the Kiev Mohyla Academy. Soon after that he wrote a tragicomedy Vladimir, in which he glorified the victory of Christianity over paganism and mocked superstition. He became a fervent supporter of the Petrovsky reforms, of Peter's absolutism and reorganization of Russia after the Western models. It was not unknown even to the ruler, especially after the panegyric which Prokopovich wrote in the praise of Peter's victory at Poltava in 1709. The emperor received him in his camp during the Pruth River Campaign in 1711, after which Prokopovich become rector of the Kiev Mohyla Academy. The emperor invited him in 1716 to move to St. Petersburg, where he preached and published his works. Then in 1718 he was ordained the bishop of Pskov and in 1720 he was ordained the Archbishop of Novgorod. He became one of the most loyal associates of Peter the Great in the reform of the church and in 1720 he personally wrote the "The Spiritual Order", which abolished the Patriarchate in Russia and introduced the Synod, where Prokopovich had the main say after the death of Stephen Javorski. In addition to numerous panegyrics and commendable letters to Peter

\footnotetext{
${ }^{15}$ Shenudzhen 1999:112.

${ }^{16}$ Rogozhin 2004: 96-99.

${ }^{17}$ Nihikov 1977: 12-45, Smirnov 1994: 29.
} 
about his reforms, military and naval victories, ${ }^{18}$ and the benefits of the worldly power over the religious one, he also wrote a catechism and a primer. The primer Первое учение отроком $^{19}$ would have a significant impact on the development of education among the Serbs in the 18th century, since a large number of items arrived with the teacher Suvorov from Russia. Later it would be repeatedly reprinted in the Rimnik printing house. ${ }^{20}$

Prokopovich's tragicomedy Vladimir was one of the first dramatic works with national and historical themes in Russia. That Prokopovich was a connoisseur of history is evidenced by the fact that, during the visit of Peter the Great to Kiev, he held a welcoming speech in which he described in detail the history of the city and the industry of Prince Vladimir and Yaroslav the Wise. ${ }^{21}$ As a teacher of rhetoric in the Kiev Mohyla Academy, he wrote in his textbook a treatise on writing Russian history. He called for a precise definition of the methods used in Russian historiography. History, according to him, should expose the facts about the past, based on which it would be possible to learn some lessons so as not to repeat the mistakes of the past in the present. According to him, one of the tasks of the future Russian historiographers was to be subjected to the criticism of fabrications and lies of foreign (Catholic) writers against the Orthodoxy and Russia. Russian historians throughout the 18th century had to comply with this principle and it would be adopted by Jovan Rajić in a modified version and he would even quote it in the preface to his History. ${ }^{22}$

In the treatise On Imperial Authority ${ }^{23}$ and The Commendable Letter on the occasion of the birth of Prince Peter Petrovich, Prokopovich justified the absolutism introduced by Peter the Great and specified the elements that may be subsumed under the theories of natural law and social contract. Among other things, he said: "Among the laws that exist in human nature we include: striving to preserve and extend the life of the individual and his kin..." In the second place he stated that democracy, the rule of aristocracy or election monarchy after the Polish model were a source of many problems and that the form of government should be adapted to the "nature" of the people. ${ }^{24}$

The most important Prokopovich's historiographical work is The History of Peter the Great from Birth to the Battle of Poltava ... ${ }^{25}$ When writing this book he used the material from the diplomatic administration, military diaries, official court journals and other authentic materials. In addition, as one of the sources he mainly used Reflections, the already mentioned book by P. P. Shafirov. This rich historical material rendered the book very reliable and documented. Prokopovich's History of Peter the Great is divided into four

\footnotetext{
${ }^{18}$ Zorin 2001: 5-34

19 Первое оученїе отрюкомъ въ немже боуквы и слоги, таже краткое толкованїе законагш десьтословї, Молитвы Господни, Съмвола въри и девьти блаженствъ, Moscow 1720.

${ }^{20}$ Kirilović 1955:15-18.

${ }^{21}$ Kirilović 1955:15-18.

22 Đurić 2009: 87-98.

${ }^{23}$ Đurić 2013: 235-246

${ }^{24}$ Rogozhin 2004: 90-91.

25 История императора Петра Великаго, от рождения его до Полтавской баталии, и взятия в плен осталных шведских войск при Переволочне, включительно, Сочиненная Феофаном Прокоповичем, после бывшим архиепископом Великаго Новагорода и Великих Лук, Изданная с обретающагося, в Кабинетской архиве дел его императорскаго величества списка, правленнаго рукою самаго сочинителя, Санктпетербург: [Тип. Мор. кадет. корпуса], 1773.
} 
books: from the emperor's birth until the beginning of the Northern War, from the beginning of the war to the foundation of St. Petersburg (1703), from 1703 to 1708, and the fourth book describes the consequences of the stay of the Swedish army in the Ukraine until the Russian victory at Poltava. ${ }^{26} \mathrm{He}$ did not reduce The History of Peter the Great only to the sequence of events, but he tried to make sense of history. Prokopovich magnified absolutism, stressing the responsibility of the monarch towards the state and the people he governed. He pointed out that the ruler should be an example to his subjects and used terms such as: the national interest, loyalty to the motherland, the glory of Russia.

The fact that Theophanes Prokopovich realized the importance of history in education is evidenced by the fact that history as a distinct discipline in secondary schools of the Petrovsky time was only taught at his private school. ${ }^{27}$

The mentioned Russian authors were forerunners of the transition of the Russian historiography into the period of modernity, as well as a methodological support and a great source for the development of works of Vasily Nikitich Tatishchev and Mikhail Lomonosov in the 18th century.

\section{REFERENCES:}

Alpatov, M.A. Russian historical thought and Western Europe, XVIII - first half XIX century, Moscow: Nauka, 1985. [Алпатов, М. А. Русская историческая мысль и западная Европа, XVIII первая половина XIX в, Москва: Наука, 1985.]

Berezovaya, L. G. and Berlyakova H. П. History of Russian Culture, Moscow: VLADOS, 2002. [Березовая, Л. Г. и Н. П. Берлякова, История Русской культуры, Москва: ВЛАДОС, 2002.]

Đurić, Đ. 'Pisci ruske istorije - M. V. Lomonosov i N. M. Karamzin', Istraživanja, 24, 2013, 235 246. [Ђурић, Ђ. „Писци Руске историје - М. В. Ломоносов и Н. М. Карамзин“, Истраживања, 24, 2013, 235-246.]

Đurić, Đ. 'Ruski uticaji na srpsku istoriografiju u drugoj polovini XVIII veka', u: D. Mikavica (ur.) Izvori o istoriji i kulturi Vojvodine, Novi Sad: Filozofski fakultet, 2009, 87-98 [Ђурић, Ђ. „Руски утицаји на српску историографију у другој половини XVIII века“ у: Д. Микавица (ур.), Извори о историји и култури Војводине, Нови Сад: Филозофски факултет, 2009, 87 98.]

Gerasimenko, Г. A. History of Russian historical science, pre-October period, Moscow: RAGS, 2002. [Герасименко, G. А. История российской исторической науки, Дооктябьрский период, Москва: РАГС, 2002.]

Karpov, G. M. Grand Embassy and the first trip abroad of Peter I, Kaliningrad: Jantar, 1997. [Карпов, Г. М., Великое посольство и первое заграничное путешествие Петра I, Калининград: Янтар, 1997.]

Kirilović, D. 'Bukvar Teofana Prokopoviča kod Srba', Zbornik Matice srpske za književnost i jezik, 3, 1955, 15-18. [Кириловић, Д. „Буквар Теофана Прокоповича код Срба“, Зборник Матице српске за књижевност и језик, 3, 1955, 15-18.]

Kostomarov, N. I. Russian history in the lives of its main figures, T III, Moscow: Book and Business, 1992. [Костомаров, Н. И. Русская история в жизнеописаниях её главнейших деятелей, $T$

\footnotetext{
${ }^{26}$ Shapiro 1993: 141-155.

${ }^{27}$ Shapiro 1993: 147.
} 
III, Москва: Книга и бизнес, 1992.]

Mankiev, A. I. Essence of Russian History, written by the high official and former representative in Sweden Prince Andrey Yakovlevich Hilkov, for the benefit of the Russian youth and all those who want to quickly acquaint themselves with Russian history, printed with a foreword about the author of the book and the relatives of the Hilkov princes (foreword by F. G: Miller), Moscow: Printed by the Imperial Moscow University, in the edition of bookmaker and university bookbinder Christian Rüdiger 1770. [Манкиев, А. И. Ядро Российской истории, сочиненное ближним стольником и бывшим в Швеции резидентом, князь Андреем Яковлевичем Хилковым, в пользу российскаго юночества, и для всех о российской истории краткое понятие иметь желающих в печать изданное, с предисловием о сочинителе сей книги, и о фамилии князей Хилковых, [предисл. Г. Ф. Миллера], Москва: Печатано при Императорском Московском Университете, Иждивением книгопродавца и Университетскаго Переплетчика Христиана Ридигера, 1770.]

Mladenović, A. 'Beogradski mitropolit Mojsej Petrović (1713-1730) i početak stvaranja srpskog književnog jezika novijeg vremena’ Arheografski prilozi, 2004-2005, 26-27. [Младеновић, А. „Београдски митрополит Мојсеј Петровић (1713-1730) и почетак стварања српског књижевног језика новијег времена“, Археографски прилози, 2004-2005, 26-27.]

Molchanov, N. Peter I, Moscow: Algorithm, 2003. [Молчанов, Н. Пётр I, Москва: Алгоритм, 2003.]

Nichikov, V. M. Feofan Prokopovich, Moscow: Misli, 1977. [Ничик, В. М. Феофан Прокопович, Москва: Мысль, 1977.]

Obolensky, M. 'About the Author "The core of Russian history" A. I. Mankeeve', Bibliographic Notes, 2, 19, 1858, 123-145. [Оболенский М. „Сведения об авторе „Ядра российской истории“ А. И. Манкееве“ Библиографические Записки, 2, 19, 1858, 123-145.]

Pekarsky, P. Science and Literature under Peter the Great, T. 2, Description of Slavic-Russian books and printing, 1698-1725 years, St. Petersburg: Public benefit 1862. [Пекарский, П. Наука $и$ литература при Петре Великом, Т. 2, Описание славяно-русских книг и типографий, 1698-1725 г2., Санктпетербург: Общественная польза 1862.]

Rogozhin, N. M. 'Peter's reforms and Russian historiography' in: Lachaeva M. Yu (ed.), Historiography Russian history until 1917. year, Moscow: Vlados 2004, 84-97. [Рогожин, Н. М. „Петровские рефорьы и русская историография“ у: Лачаева М. Ю. (ур), Историография истории России, до 1917. года, Москва: Владос, 2004, 84-97.]

Smirnov, V. G. Feofan Prokopovich, Moscow: Soratnik, 1994. [Смирнов, В. Г. Феофан Прокопович, Москва: Соратник 1994.]

Shapiro, A. Russian historians from ancient times to 1917, Moscow: Kultura, 1993. [Шапиро, А. Л. Русская историография с древнейших времен до 1917.2, Москва: Культура, 1993.]

Shenudzhen, E. A. Historiography, History of Historical Science, Maykop: Adyghe State University, 1999. [Шенуджен, Э. А. Историография, История исторической науки, Майкоп: Адыгейски государствени университет, 1999.]

Zorin A. 'Feofan Prokopovich,' in: Kurilkina A. R. (ed.), Russian literature of XVIII century, Moscow, SLOVO 2001, 5-34. [Зорин, А. „Феофан Прокопович“, у: Курилкина А. Р. (ур.) Русская литература ХVІІІ века, Москва, СЛОВО, 2001, 5-34.] 
ЂОРЪЕ ЂУРИЋ

Универзитет у Новом Саду, Филозофски факултет, Одсек за историју

\section{РУСКА ИСТОРИОГРАФИЈА ПЕТРОВСКЕ ЕПОХЕ}

\section{Резиме}

Писање историје у у епохи Петра Великог модернизовано је као и многа поља друштвеног и културног живота Русије у време овог владара. Значајно се увећао број докумената који су настали као последица оснивања нових Одсека и Одељења у државној управи и администрацији. Ови документи постаће прворазредни историјски извори за писање савремене историје. Раније вођење хроника и писање историја полако је из делокруга цркве прелазило у државне послове. Шта више, Петар је, разумевајући значај историје за политику, лично давао препоруке како треба писати историју. Имајући у виду западне узоре, он је будућим руским ауторима налагао да историју не пишу више „од најстаријих времена“ по библијској форми, већ да пишу световну историју, којој је у центру пажње руска држава. Наравно, при томе посебну пажњу требало је обратити на њега лично и описати његове походе, реформе и друге догађаје који га представљају као модерног и успешног владара. Посебно значајни аутори руске историје из овог периода били су: Алексеј Манкијев, Фјодор Поликарпов, Петар Шафиров, Борис Куракин и Теофан Прокопович. Сви они били су искуснои државни делатници који су били укључени у спровођење петровских реформи. У својим делима су почели прихватати западне узоре и на пољу методологије историописања и тиме начинили значајан отклон од раније руске средњовековне - хроничарске традиције. Тако су они постали претече преласка руске историографије у период модерности и методолошки али и изворни ослонац за настанак дела Василија Никитича Татишчева и Михаила Васиљевича Ломоносова у 18. веку.

Кључне речи: Руска историографија, Епоха Петра Великог, Историјска свест, Теофан Прокопович, Алексеј Манкијев, Историја Русије, Фјодор Поликарпов, Петар Шафиров, Борис Куракин. 